Research Organisation because he wished his assis tants to receive the maximum credit. It remains, however, to say that every investigator had been helped to the full by his wise and able guidance.

F. S. SinnatT.

\section{Mr. L. A. Boodle}

THE death of Mr. Leonard Alfred Boodle, formerly assistant keeper of the Jodrell Laboratory, Royal Botanic Gardens, Kew, on August 22, has removed from our midst a very learned botanist and a most conscientious and devoted public servant.

Boodle started his botanical career at the Royal College of Science, and after taking his A.R.C.S. he was for seven years demonstrator at the College under the late Dr. D. H. Scott. Soon after Dr. Scott went to Kew as honorary keeper of the Jodrell Laboratory, Boodle joined him as his private assistant, and it was then that Boodle's valuable work on plant anatomy commenced. Before that he visited South Africa and worked on marine algæ, with the late Mr. George Murray. The genus Boodlea was named after him.

When Dr. Scot, resigned his honorary keepership of the Laboratory in 1906, Boodle was put in charge, having been appointed an assistant at Kew in 1904 . He was appointed assistant keeper of the Laboratory in 1909 and retired under the age limit in May 1930.

Boodle was blessed with a splendid memory and had a remarkable knowledge of botany and botanical literature; he was a very valuable critic. Diffident of his own powers and most meticulous in all he undertook, he spared no pains in working out fully any problem presented to him, but his published work was not very large and much first-class research work he carried out, unfortunately, was never published. His papers on the vascular structure of the Pteridophyta are a worthy memorial of his careful and exact methods.

Prof. E. J. Salisbury writes: "H.e was a man of whose profound anatomical knowledge and surefootedness we all had the greatest respect. His extreme modesty and retiring nature led to many not appreciating to the full his great gifts."

ArThur W. Hill.

\section{Dr. M. Benjamin}

WE have learnt with deep regret of the death in a recent aeroplane accident of Dr. M. Benjamin, while engaged on work for which he was seconded from industry to the Ministry of Supply. He was a physicist of great promise who had begun to make his mark in pure science as well as in applications to industry.

His work in pure physics consists of a number of careful and interesting studies of electron emission from various types of surfaces. The earliest (Benjamin and Rooksby, Phil. Mag., 15, 810 ; 16, 519 ; 1933) cleared up in a remarkable way the peculiar features of the emission given by coatings of mixed oxides of strontium and barium. Then followed studies of the migration of barium and thorium ions over various surfaces, the resulting changes in thermionic emission being used to indicate the migration (and evaporation). Quite recently, in collaboration with Jenkins, Benjamin was engaged in the study of electron emission from metal points as a function of direction of emission and surface conditions, studies which are in course of publication by the Royal Society. The observed emission patterns were of great variety and complexity; they promise to provide new and important information for the electron theory of metals, and of the nature and properties of a metal point formed on a single crystal.

There was another side of Benjamin's life and character. He was one of those who took kindly to the practice of maintaining frequent personal contacts with the industry which, in effect, gave men such as him their chance. Although this left only part of his time and energies for his researches, it provided a fund of knowledge on recurrent but unexplained phenomena demanding inquiry. For him, however, the main urge was probably rather in the fact that, in the making of thermionic valves in thousands, the slightest misunderstanding leads to waste and delay; of these he was most impatient, and difficulties increased his activities in factory and laboratory to a fury. Nevertheless, his actual approach was always one of friendly interest, and he was as apt to learn as to teach. This attitude encouraged in all manner of people responsiveness and trust, so that his interventions were not merely accepted but were often claimed with insistence. His most recent work brought out his qualities to the full, with results which will be far-reaching.

That his colleagues in the Laboratory feel his loss to be most grievous goes without saying, but there will be many elsewhere who will miss him and will know the reasons for these feelings.

\section{Prof. C. Bartel}

Nwws has reached his friends in Britain that Prof. Casimir Bartel, the distinguished mathematician and former Polish prime minister, was recently executed by the Germans for alleged co-operation with the Russians. His death, at the age of fifty-nine, deprives Poland of a man who would have been most useful to the nation in the future reconstruction after the country's independence is restored.

Born at Lwow, Bartel received a technical education before entering the University of Munich to study mathematics. When he returned to Lwow he taught mathematics (in particular geometry) at the Polytechnic High School, becoming in turn lecturer, assistant professor, full professor, rector and finally principal of this institution of university rank.

In science, Prof. Bartel was the most eminent of contemporary Polish mathematicians. After the War of 1914-18, when Poland regained its liberty, the nation depended upon its men of science and learning to undertake its leadership, and Prof. Bartel was among those who responded to the country's call. In 1919 he accepted the post of minister for railways and communications in Prof. Paderewski's first government, and he was therefore largely 
responsible for co-ordinating the three systems previously forming part of the German, Austrian and Russian systems. He resigned in 1922, but four years later became first premier and then deputy prime minister under Marshal Pilsudski. He retired from politics in 1930 and returned to Lwow to resume his scientific and academic interests.

When the Germans occupied Lwow they closed. the University and Polytechnic and arrested many eminent men. The fate of Prof. Bartel gives rise to concern for the safety of the other distinguished Polish savants still in Nazi hands.

G. D.

WE regret to announce the following deaths :

Mr. H. S. Ball, O.B.E., principal of the School of Metalliferous Mining, Cornwall, on September 26, aged fifty-three.
Mr. R. T. Baker, formerly curator of the Technological Museum, Sydney, a well-known authority on Australian eucalypts and pines, on July 14, aged eighty-six.

Mr. D. P. Petrocochino, C.B.E., a well-known benefactor to Greek archæology, one of the founders of the Anglo-Hellenic League, recently in Athens, aged eighty.

Mr. A. H. Smith, C.B., keeper of Greek and Roman antiquities in the British Museum during 19C9-25, on September 27, aged eighty.

Prof. Myron Harmon Swenk, chairman of the Department of Entomology in the University of Nebraska, aged fifty-eight.

Prof. Isaac Weinberg, an authority on the Amharic and Abyssinian languages, recently in Warsaw, aged sixty-three.

\section{Conference on Science and World ORDER}

NEWS AND VIEWS

\section{Message from H.M. the King}

THe following message from H.M. the King was sent to the Conference on Science and World Order, held during September 26-28: "I thank you sincerely for your message on the occasion of the opening of the conference held by the Division of the British Association for Social and International Relations of Science which was so wisely established a few years ago. The social benefits which scientific research, by free practice and under right guidance, can bestow on all mankind grow ever greater. It is right that such benefits should be shared among all peoples alike. I am happy, therefore, to join with you in welcoming the many distinguished scientists from oversea and in thanking them for the free gift of their knowledge. I sincerely hope that this valuable interchange of ideas will further the lofty aims which the British Association has consistently produced since its foundation.-GEORGE R.I."

\section{The Prime Minister's Message}

The Prime Minister sent the following message to the Conference: "One of our objects in fighting this war is to maintain the right of free discussion and the interchange of ideas. In contrast to the intellectual darkness which is descending on Germany, the freedom that our scientists enjoy is a valuable weapon to us, for superiority in scientific development is a vital factor in the preparation of victory. The presence of representatives of so many different nations is striking proof of that universal desire for liberty of thought which all the power of the Gestapo will never entirely stamp out.

"It will take a long time for the civilised Powers to repair the trail of material and moral havoc which Germans leave behind them. It will require all the resources of science. But I look forward to the day when the scientists of every nation can devote all their energies to the common task, and I wish you every success in the work that you are undertaking now."

\section{The Foreign Secretary's Statement}

AT a luncheon given to the delegates to the Conference by the British Council on September 25, Mr. Anthony Eden, Secretary of State for Foreign Affairs, said that there was never a more appropriate time for such a conference; the representatives of the free scientific spirit from many lands were in Great Britain-and here of their own free will. They were to discuss what kind of world will be created when Hitlerism is destroyed. In recent generations science has set free new powers for our use, and, if we so determine, for our incalculable good. But lately, in the hands of evil men, these powers have been used to destroy all that is good in order to dominate and enslave all that is humane. No one action can more clearly reveal the present German spirit than the replacement at the University of Heidelberg of the inscription, "To the living spirit", by "To the German spirit". This German spirit has made German scientists slaves of the regime, and opposed to all that science represents. That spirit must be overcome.

We have called on men of science, Mr. Eden said, in the cause for which we are fighting. We shall need them no less in the cause for which we are working in peace. The advent of the machine has brought great material gain, but it has brought its terrors also. It has brought astonishing material adventages to many, but it has led to inequalities, to much selfishness, to unfair division, and to materialism. If after the War we are to remove the fear of want as well as of war, science and statecraft must work together. "In war-time, diplomacy is the servant of strategy. In peace-time I pray that it may be the servant of science." 